\title{
Hubungan Kebersihan Rumah Terhadap Kejadian Ispa Pada Balita Di Dusun Jabon Desa Sisik Wilayah Kerja Puskesmas Bagu Kecamatan Pringgarata Kabupaten Lombok Tengah Tahun 2018
}

\author{
Lalu Sulaiman $^{1)^{*}}$, Muhammad Amrullah $^{1)}$, Fuji Khirani $^{(1)}$, Nurul Hidayah $^{1)}$ \\ Email: aam.dais.ad@gmail.com \\ 1) Universitas Qamarul Huda Badaruddin Bagu
}

\begin{abstract}
ABSTRAK
Infeksi Saluran Pernafasan Akut (ISPA) merupakan penyakit yang sering dialami balita dengan gejala batuk, pilek, panas selama dua minggu terakhir. Survey mortalitas yang dilakukan oleh Subdit ISPA tahun 2016 menempatkan ISPA sebagai penyebab kematian bayi terbesar di Indonesia dengan persentase 32,10\%. Lombok Tengah menunjukkan bahwa kasus terbanyak adalah Infeksi Saluran Pernafasan Akut dengan jumlah 19748 kasus, sedangkan di wilayah kerja Puskesmas Bagu Lombok Tengah tahun 2016, tercatat kasus ISPA pada Balita sebanyak 1272 kasus, kemudian pada tahun 2017 sebanyak 1204 kasus. ISPA dapat diakibatkan oleh faktor internal dalam rumah yang meliputi faktor perilaku, individu balita, lingkungan fisik rumah, dan faktor sosial. Penelitian ini bersifat analitik dengan pendekatan cross sectional. Adapun tujuan penelitian ini adalah untuk mengetahui hubungan kebersihan rumah terhadap kejadian ISPA pada balita. Penelitian dilakukan pada bulan juni 2018 dengan populasi sebanyak 46 kepala keluarga yang memiliki balita sedangkan sampel dalam penelitian ini sebanyak 32 kepala keluarga. Hasil penelitian ini menunjukkan bahwa 37,5\% atau 12 balita mengalami ISPA dan $62,5 \%$ atau 20 balita yang tidak mengalami ISPA. Selanjutnya berdasarkan hasil analisa data diketahui bahwa ada hubungan antara kebersihan rumah terhadap kejadian ISPA pada balita menggunakan uji chi-square dengan nilai value $\mathrm{p}=0,002$. Kesimpulan : ada hubungan yang signifikan antara kebersihan rumah terhadap kejadian ISPA pada balita. Saran : rekomendasi hasil penelitian ini dapat meningkatkan pengetahuan masyarakat serta meningkatkan pendidikan dan penyuluhan terkait kebersihan rumah dan kejadian ISPA pada balita.
\end{abstract}

Kata Kunci : Kebersihan Rumah dan Kejadian ISPA pada Balita

\begin{abstract}
Acute Respiratory Infection (ARI) is a disease often experienced by toddlers with symptoms of cough, runny nose, fever for the past two weeks. Mortality survey conducted by the ISPA Sub Directorate in 2016 places the ARI as the biggest cause of infant death in Indonesia with a percentage of $32.10 \%$. Central Lombok shows that the most cases are Acute Respiratory Infection with 19748 cases, whereas in the working area of Bagu Lombok Central Health Center in 2016, there were 1272 cases of ARI in Toddlers, then in 2017 there were 1204 cases. ARI can be caused by internal factors in the home which include behavioral factors, individual toddlers, the physical environment of the home, and social factors. This research is analytic with cross sectional approach. The purpose of this study was to determine the relationship of home cleanliness to ARI events in infants. The study was conducted in June 2018 with a population of 46 households with children under five, while the sample in this study were 32 households. The results of this study indicate that $37.5 \%$ or 12 toddlers experience ARI and $62.5 \%$ or 20 toddlers who do not experience ARI. Furthermore, based on the results of data analysis it is known that there is a relationship between house cleanliness on ARI events in infants using the chi-square test with a value of $p=0.002$. Conclusion: there is a significant relationship between house cleanliness on ARI in children under five. Suggestion: the recommendations of the results of this study can increase public knowledge and improve education and counseling related to home hygiene and ARI events in infants.
\end{abstract}

Keywords : House Cleanliness and ARI Events in Infants 


\section{A. LATAR BELAKANG}

Suatu rumah baru dapat dikatakan memenuhi syarat kesehatan apabila dapat memenuhi kebutuhan fisiologis (meliputi pencahayaan, suhu, dan ruang gerak yang cukup, terhindar dari kebisingan yang mengganggu tidur dan sebagainya), kebutuhan psikologis (seperti privacyyang cukup, komunikasi yang sehat antar anggota keluarga/penghuni rumah dan sebagainya), memenuhi persyaratan pencegahan penularan penyakit antar keluarga atau penghuni rumah, memenuhi persyaratan pencegahan terjadinya kecelakaan baik yang timbul karena keadaan luar maupun dalam rumah [1].

Komponen rumah dan lingkungannya yang tidak memenuhi syarat kesehatan merupakan faktor resiko sebagai sumber penularan berbagai jenis penyakit, khususnya penyakit yang berbasis lingkungan [2]. Akibat dari rumah yang tidak sehat akan menimbulakan dampak negatif terhadap kesehatan manusia itu sendiri dan dampak salah satunya yaitu penyakit infeksi Saluran Pernafasan Akut (ISPA), terutama pada balita yang rentan terhadap penyakit.

Infeksi Saluran Pernafasan Akut (ISPA) merupakan penyebab utama morbiditas dan mortalitas penyakit menular di dunia. Angka mortalitas ISPA mencapai 4,25 juta setiap tahun di Dunia. Berdasarkan prevalensi ISPA tahun 2016 di Indonesia telah mencapai 25\% dengan rentang kejadian yaitu sekitar $17,5 \%-41,4 \%$ dengan 16 Provinsi diantaranya mempunyai prevalensi di atas angka nasional. Selain ituISPA juga sering berada pada daftar 10 penyakit terbanyak di rumah sakit.Survei mortalitas yang dilakukan oleh Subdit ISPA tahun 2016 menempatkanISPA sebagai penyebab kematian bayi terbesar di Indonesia denganpersentase $32,10 \%$ dari seluruh kematian balita [3].

Indonesia selalu menjadi urutan pertama penyebab kematian ISPA pada kelompok bayi dan balita. Di indonesia, kejadian ISPA tertinggi pada provinsi Nusa Tenggara Timur (41,7\%), Papua $(31,1 \%)$, Aceh $(30,0 \%)$, Nusa Tenggara Barat $(28,3 \%)$, dan Jawa Timur $(28,3 \%)$.
Sedangkan di provinsi lain yaitu sebanyak $15,7 \%$ [4].

Provinsi NTB merupakan salah satu provinsi dengankejadian ISPA yang tertinggi(28,3\%). Di salah satu daerah provinsiNTB yaitu Kabupaten Lombok Tengah menunjukkan bahwa kasus terbanyak adalah Infeksi Saluran Pernafasan Akut (ISPA) dengan jumlah 19748 kasus, sedangkan di wilayah kerjaPuskesmas Bagu Kecamatan Pringgarata Kabupaten Lombok Tengah, laporan Pencatatandan Pelaporan Terpadu (P2 Terpadu) Puskesmas Bagu tahun 2016, tercatat kasusISPA pada Balita sebanyak 1272 kasus, kemudian pada tahun 2017 sebanyak 1204 kasus. Fakto-faktor yang mempengaruhi ISPA pada balita salah satunya yaitu kebersihan rumah, rumah yang luas ventilasinya tidak memenuhi syarat kesehatan akan mempengaruhi kesehatan penghuni rumah, hal ini disebabkan karena proses pertukaran aliran udara dari luar ke dalam rumah tidak lancar, sehingga bakteri penyebab sakit ISPA yang ada di dalam rumah tidak dapat keluar [5].

Dari studi pendahuluan yang dilakukan oleh peneliti pada tanggal 26 februari sampai dengan 26 maret 2018 di Desa Sisik yang terdiri dari delapan Dusun diataranya Dusun Paok Odang, Sisik Goak, Kelane, Sisik Timur, Sisik Barat, Samarkaton, Karang kebon dan Jabon. Dusun jabon merupakan Dusun dengan jumlah 432 jiwa, terdiri dari $142 \mathrm{KK}$, yang memiliki kasus ISPA cukup tinggi dengan persentase 29,3\%atau sebanyak 44 kasus ISPA. Mata pencaharian masyarakat di dusun tersebut rata-rata bertani. Masyarakat yang mata pencahariannya bertani rata-rata jarang membersihkan ruangan bahkan lingkungan rumah karena mereka lebih sering berada di sawah ketika siang hari sehingga rumah mereka terlihat kurang bersih, ventilasi rumah yang kurang menyebabkan pencahayaan didalam ruangan menjadi remang-remang, udara didalam rumah juga menjadi pengap karena pertukaran udara menjadi tidak sesuai.

Pertukaran udara yang tidak sesuai akan berdampak berkurangnya $\mathrm{O} 2$ dalam ruangan yang menyebabkan daya tahan tubuh menurun, 
sehingga mempercepat timbulnya penyakit saluran pernafasan.

\section{B. METODE PENELITIAN}

Penelitian ini merupakan penelitian analitik dengan pendekatan cross sectional di mana data yang menyangkut variabel bebas atau resiko dan variabel terikat atau variabel akibat, akan dikumpulkan dalam waktu yang bersamaan

Populasi pada penelitan ini adalah semua Kepala Keluarga (KK) yang mempunyai balita berusia nol sampai lima tahun di Dusun Jabon Desa Sisik, Kecamatan Pringgarata,kabupaten Lombok tengah yang berjumlah 46 Kepala Keluarga (KK) yang memiliki balita dan jumalah sampel yang digunakan pada penelitian ini adalah 31,5 orang yang dibulatkan menjadi 32 orang responden, sehingga bear sampel penelitian ini adalah 32 orang.

Pada penlitian ini teknk sampe yang digunakan adalah simple random sampling yaitu jenis probabilitas yang paling sederhana. Untuk mancapai sampling ini, setiap elemen diseleksi secara acak. Instrumen yang digunakan dalam penelitian ini adalah cheklist dengan uji validitas, yang terdiri dari 10 pertanyaan, setelah di uji instrumen 10 pertanyaan tersebut dinyatakan valid. Uji validitas instrumen data menggunakan person product moment dengan $r$ hitung $>0,5140$. Sedangkan uji Reabilitas untuk kejadian ISPA pada balita menggunakan uji crombach alpha dengan nilai 0,976 maka hasil uji realibilitas tersebut reliabel.

\section{HASIL PENELITIAN \\ 1. Jenis Kelamin Responden}

Dari tabel $1 \mathrm{di}$ atas menunjukkan bahwa dari 32 responden penelitian terdapat 3 orang
(9\%) merupakan responden penelitian yang berjenis kelamin laki- laki dan 29 orang (91\%) merupakan resonden penelitian yang berjenis kelamin perempuan.

Tabel 1. Distribusi Frekuensi Berdasarkan Jenis Kelamin Responden

\begin{tabular}{|c|c|c|c|}
\hline No & $\begin{array}{c}\text { Jenis } \\
\text { Kelamin }\end{array}$ & Jumlah & $\%$ \\
\hline 1 & Laki- laki & 3 & $9 \%$ \\
\hline 2 & Perempuan & 29 & $91 \%$ \\
\hline \multicolumn{2}{|r|}{ Total } & 32 & $100 \%$ \\
\hline
\end{tabular}

2. Jenis kelamin balita

Tabel 2. Distribusi Frekuensi Berdasarkan Jenis Kelamin balita

\begin{tabular}{cccc}
\hline No & $\begin{array}{c}\text { Jenis } \\
\text { Kelamin }\end{array}$ & Jumlah & $\%$ \\
\hline 1 & Laki- laki & 17 & $53 \%$ \\
2 & Perempuan & 15 & $47 \%$ \\
\hline & Total & 32 & $100 \%$ \\
\hline
\end{tabular}

Dari tabel diatas menunjukkan bahwa dari 32 responden penelitian terdapat 17 orang $(53 \%)$ merupakan responden penelitian yang berjenis kelamin laki- laki dan 15 orang (47\%) merupakan resonden penelitian yang berjenis kelamin perempuan.

\section{1) Umur}

Berdasarkan umur di Dusun Jabon Desa Sisik Wilayah Kerja Puskesmas Bagu Kecamatan Pringgarata Kabupaten Lombok Tengah dapat dilihat pada tabel berikut :

$$
\text { Umur responden }
$$

Tabel 3. Distribusi Frekuensi Berdasarkan Umur Responden

\begin{tabular}{cccc}
\hline No & Umur & Jumlah & $\%$ \\
\hline 1 & $18-28$ tahun & 16 & $50 \%$ \\
2 & $29-35$ tahun & 11 & $34 \%$ \\
& $36-45$ tahun & 5 & $16 \%$ \\
\hline \multicolumn{2}{l}{ Total } & 32 & $100 \%$ \\
\hline
\end{tabular}

Dari tabel diatas menunjukkan bahwa dari 32 responden penelitian terdapat sebanyak 16 (50 \%) responden yang berumur 18-28 tahun, sebanyak 11 (34\%) responden yang berumur 2935 tahun, dan terdapat sebanyak 5 (16 \%) responden yang berumur 36-45 tahun.

2) Umur balita 
Tabel 4. Distribusi Frekuensi Berdasarkan Umur Balita

\begin{tabular}{cccc}
\hline No & Umur & Jumlah & $\%$ \\
\hline 1 & $<1$ tahun & 2 & $6,25 \%$ \\
2 & $1-3$ tahun & 22 & $68,75 \%$ \\
3 & $>3-5$ tahun & 8 & $25 \%$ \\
\hline \multicolumn{2}{c}{ Total } & 32 & $100 \%$ \\
\hline
\end{tabular}

Dari tabel diatas menunjukkan bahwa dari 32 responden penelitian terdapat sebanyak 2 $(6,25 \%)$ balita yang berumur $<1$ tahun, sebanyak $22(68 \%)$ balita yang berumur 1-3 tahun, dan terdapat sebanyak 8 (25\%) balita yang berumur >3-5 tahun.

3) Jumlah Balita Dalam Keluarga

Tabel 5. Distribusi Frekuensi Berdasarkan jumlah Balita Dalam Keluarga

\begin{tabular}{cccc}
\hline No & Kategori & Jumlah & Persen \\
\hline & 1 balita & 27 & \\
& 2 balita & 5 & \\
\hline & Total & 32 & \\
\hline
\end{tabular}

3. Kejadian ISPA

Berdasarkan penyakit yang diderita anak balita (0-5 tahun) dikelompokkan dalam ISPA dan tidak ISPA dengan hasil sebagai berikut :

Tabel 6. Distribusi kejadian ISPA Pada Anak Balita (0-5 tahun)

\begin{tabular}{clcc}
\hline No & Kategori & Jumlah & Persen \\
\hline 1 & ISPA & 12 & $37,5 \%$ \\
2 & Tidak & 20 & $62,5 \%$ \\
& ISPA & & \\
\hline \multicolumn{2}{r}{ Total } & 32 & $100 \%$ \\
\hline
\end{tabular}

Menurut tabel diatas menunjukkan bahwa sebanyak 12 (37,5 \%) balita (0-5 tahun) mengalami ISPA dan $20(62,5 \%)$ balita tidak mengalami ISPA.

1) Kebersihan Rumah

Kebersihan rumah diketahui dengan penerapan indikator kebersihan rumah dan dikategorikan dalam kelompok bersih dan tidak bersih, hasilnya adalah :

Tabel 7. Distribusi Kebersihan Rumah

\begin{tabular}{llcc}
\hline No & $\begin{array}{c}\text { Indikator } \\
\text { kebersihan rumah }\end{array}$ & Jumlah & $\%$ \\
\hline 1 & Bersih & 18 & $56 \%$ \\
2 & Tidak Bersih & 14 & $44 \%$ \\
\hline & Total & 32 & $100 \%$ \\
\hline
\end{tabular}

Menurut tabel diatas dari 32 rumah responden sebagian besar termasuk Bersih yaitu sebanyak 18 (56 \%) rumah KK dan sebagian yang termasuk kategori tidak bersih yaitu 14 (44 $\%)$ rumah $\mathrm{KK}$

2) Hubungan Kebersihan Rumah Terhadap Kejadian ISPA

Sesuai dengan tujuan penelitian dilakukan uji statistik untuk mengetahui hubungan kedua variabel penelitian dan hasilnya adalah sebagai berikut :

Tabel 8. Tabulasi Silang Kebersihan Rumah Terhadap Kejadian ISPA Pada Balita

\begin{tabular}{cccccccc}
\hline No & $\begin{array}{c}\text { Kategori } \\
\text { kebersihan } \\
\text { rumah }\end{array}$ & \multicolumn{4}{c}{ Kategori ISPA } & Jumlah \\
\cline { 3 - 6 } & & ISPA & \multicolumn{2}{c}{$\begin{array}{c}\text { Tidak } \\
\text { ISPA }\end{array}$} & & \\
\cline { 3 - 6 } & & $\mathrm{N}$ & $\%$ & $\mathrm{~N}$ & $\%$ & $\mathrm{~N}$ & $\%$ \\
\hline 1 & Bersih & 1 & 3,1 & 7 & 21,9 & 18 & 56,2 \\
2 & Tidak bersih & 11 & 34,4 & 13 & 40,6 & 14 & 43,8 \\
\hline & Total & 12 & 37,5 & 20 & 62,5 & 32 & 100 \\
\hline
\end{tabular}

Sumber : Hasil Uji Statistik Responden

Menurut Tabel 9. Di Atas Distribusi Terbanyak Adalah Anak Balita Yang Tidak ISPA dan kebersihan rumah yang tidak bersih sebanyak $13(40,6 \%)$ keluarga, dan paling sedikit anak balita yang ISPA yang kebersihan rumahnya bersih yaitu 1 orang $(3,1 \%)$.

Hasil uji chi square dengan SPSS diperoleh nilai signifikan pearson chi square sebesar 0,002 , karna nilai lebih kecil dari 0,005 berarti ada hubugan yang bermakna antara variabel kebersihan rumah dengan kejadian ISPA pada balita (0-5 tahun)

\section{PEMBAHASAN}

\section{Kejadian ISPA Pada Balita (0-5 tahun)}

ISPA merupakan salah satu penyakit yang sering terjadi pada bayi dan balita dimana pada masa tersebut imunitas bayi dan balita belum baik dan lumen saluran nafasnya masih sempit. Oleh sebab itu resiko kejadian ISPA pada bayi dan anak lebih tinggi jika dibandingkan dengan orang dewasa [6].

Kejadian penyakit ISPA pada balita dalam penelitian ini berdasarkan gejala penyakit balita 
yang diderita selama satu bulan terakhir, apabila ada gejala batuk, pilek, serak, atau dengan gejala lain selama lebih dari 14 hari dalam satu bulan terakhir maka dikategorikan sakit ISPA. Kebersihan rumah keluarga yang distribusi kebersihan nya masuk dalam kategori tidak bersih serta komponen rumah keluarga yang tidak memenuhi syarat, hal ini berkaitan dengan perekonomian, kepadatan hunian dan kebiasan serta pengetahuan masyarakat yang masih kurang. Salah satu cara untuk menanggulanginya dengan memberikan banyak informasi khususnya mengenai kesehatan sehingga pengetahuan masyarakat meningkat.

Pada penelitian ini yang menjadi responden adalah anak balita yang berumur 0-5 tahun, dimana pada masa balita ini daya tahan tubuh anak belum maksimal sehingga rentan terkena penyakit- penyakit infeksi termasuk ISPA.hasil penelitian menunjukkan bahwa selama waktu penelitian dari 32 sampel penelitian sebanyak 12 anak balita yang mengalami ISPA. .

\section{Kebersihan Rumah}

Hasil penelitian didapatkan, balita yang tidak sakit ISPA yaitu sebagian tinggal dirumah yang masuk kedalam kategori bersih dan hanya sebagian yang terkena ISPA tinggal dirumah yang tidak masuk kedalam kategori tidak bersih.

Berdasarkan tabel 7. tentang penilaian indikator kebersihan rumah menunjukkan bahwa kebersihan rumah di Dusun Jabon Desa Sisik Wilayah Kerja Puskesmas Bagu Kecamatan Pringgarata Kabupaten Lombok Tengah dalam kategori bersih yaitu sebanyak 18 rumah (56\%), dengan kata lain melaksanakan indikator kebersihan rumah yang berjumlah sepuluh indikator sedangkan yang tidak bersih 14 rumah (44\%), Hal ini disebabkan karena beberapa komponen rumah yang tidak dimiliki oleh sebagian responden antara lain langit langit, jendela kamar tidur dan pencahayaan yang kurang sehingga mengurangi penilaian terhadap komponen rumah serta pekerjaan dan keseharian penghuni rumah yang jarang berada dirumah. Komponen rumah merupakan salah satu contoh dari faktor lingkungan fisik. Lingkungan fisik yang nampak ini akan berpengaruh jika memang dalam kondisi yang tidak sehat, sehingga sebisa mungkin tetap dalam kondisi sehat..

Rumah sehat menurut Krieger dan Higgins pada 2002, harus tersedia sarana dan prasarana yang meliputi ketersediaan air bersih serta sanitasi pembuangan sampah. Konsep dari perumahan sehat melibatkan pendekatan sosiologis dan teknis pengelolaan faktor risiko dan berorientasi pada lokasi bangunan perumahan, kualifikasi, adaptasi terhadap lingkungan sekitar, manajemen dan pemeliharaan rumah dengan lingkungan di sekitarnya, serta konsep dari rumah sehat mencakup unsur ketersediaan sarana dan prasarana sanitasi yaitu air bersih atau sarana yang memadai untuk memasak dan mencuci, sarana untuk pembuangan kotoran manusia maupun limbah lainnya serta yang paling utama penyediaan air minum [7].

Kriteria rumah yang baik dipengaruhi oleh beberapa kriteria antara lain kepadatan hunian, ventilasi (alamiah maupun buatan), kelembaban, suhu, pencahayaan, dan kriteria- kriteria lainnya. Dalam penelitian ini ditemukan hasil bahwa indikator kebersihan rumah yang banyak tidak dilakukan oleh keluarga adalah pertukaran udara didalam rumah yang berhubungan dengan ventilasi, langit- langit, tembok, ruangan, dan kamar tidur balita yang kurang bersih.

Hal ini disebabkan pada penilaian komponen rumah, sebagian responden tidak memiliki jendela kamar tidur sehingga pertukaran udara didalam kamar tidur tidak bersih. Selain itu, responden yang memilki jendela kamar tidur tidak membuka jendela dengan beberapa macam alasan antara lain khawatir nyamuk masuk ke dalam kamar, keseharian penghuni rumah disawah sehingga tidak membuka jendela sama sekali, jarak tiap rumah yang berdekatan sehingga mereka cenderung tidak membuka jendela kamar tidur setiap hari. Padahal kebiasaan membuka jendela kamar tidur ini menurut Notoatmodjo, adalah untuk memenuhi syarat kesehatan di mana untuk dapat lebih 
memberikan kesejukan pada ruangan, sebaiknya jendela dan lubang angin selalu terbuka serta dapat menerima masuknya cahaya dari luar [5].

\section{Hubungan Kebersihan Rumah Terhadap Kejadian ISPA Pada Balita (0-5 tahun)}

Berdasarkan tabel 4.8 tabulasi silang Hasil penelitian menunjukkan bahwa ada hubungan yang bermakna antara variabel kebersihan rumah dengan kejadian ISPA pada balita (0-5 tahun) (nilai pearson chi square $=0,002$ ). Hal ini bermakna kebersihan rumah dalam kehidupan sehari- hari berkontribusi terhadap kejadian ISPA pada balita.

Dari tabel tersebut menunjukkan bahwa dari 32 unit rumah dengan rumah yang memenuhi kategori bersih dan penderita ISPA sebanyak $(3,1 \%)$ yaitu 1 orang (balita), komponen rumah yang memenuhi kategori bersih dan bukan penderita ISPA sebanyak (21,9\%) yaitu sebanyak 7 orang (balita). Sedangkan komponen rumah yang tidak memenuhi kategori bersih dan penderita ISPA sebanyak $(34,4 \%)$ yaitu sebanyak 11 orang (balita) dan komponen rumah yang tidak memenuhi kategori bersih dan tidak ISPA sebanyak $(62,5 \%)$ yaitu sebanyak 13 orang (balita).

Hal ini disebabkan karena beberapa dari komponen rumah yang tidak dimiliki oleh sebagian besar responden antara lain langit langit, jendela kamar tidur dan pencahayaan yang kurang. Hal ini berarti bahwa kebersihan rumah yang tidak bersih dapat menjadi risiko terkena ISPA pada anak Balita. Menurut Azwar, bahwa agar terhindar dari penularan penyakit dan kecelakaan di dalam rumah maka rumah yang sehat harus dibangun sedemikian rupa sehingga dapat melindungi penghuni dari kemungkinan terjadinya bahaya atau kecelakaan dan penularan penyakit [8].

Jendela kamar tidur sangat penting untuk sirkulasi udara sesuai dengan teori Azwar, yang menyatakan bahwa dengan adanya jendela sebagai lubang angin maka di dalam ruangan tidak pengap dan dapat terhindar dari penularan
ISPA yang disebabkan oleh virus dan bakteri. Sedangkan pada pencahayaan, menurut teori Notoatmodjo [5], menyatakan bahwa kurangnya cahaya yang masuk ke dalam ruangan rumah terutama cahaya matahari di samping kurang nyaman juga merupakan media yang baik untuk hidup dan berkembangnya bibit-bibit penyakit [5].

Resiko terkena ISPA juga dapat disebabkan oleh penyediaan air bersih sebagian responden masih mengggunakan air dari sumur atau air dari penampungan hujan yang tidak memenuhi syarat kesehatan sehingga memungkinkan terjadinya penularan penyakit bawaan dengan kondisi daya tahan tubuh yang lemah akan memudahkan terjadinya penularan penyakit termasuk penyakit ISPA. sarana pembuangan kotoran atau limbah sebagian responden tidak memiliki sarana pembuangan kotoran termasuk kamar mandi dan sarana pembuangan air limbah di rumahnya sehingga mereka melakukan semuanya di batang yaitu bangunan semi permanen yang dibangun di atas permukaan sungai yang digunakan masyarakat untuk mandi, buang kotoran, buang sampah dan mencuci sehingga hal ini dapat menyebabkan penularan penyakit melalui udara yang kotor dan di lingkungan sekitarnya sehingga memungkinkan untuk terjadinya penularan penyakit terutama penyakit pernapasan. Menurut Kasnodiharjo, jenis sarana penampungan yang tidak memadai akan mencemari lingkungan sekitar dan sekaligus meningkatkan risiko penularan penyakit terhadap masyarakat karena kotoran manusia di permukaan tanah lama kelamaan menjadi kering dan setelah kering terbawa tiupan angin bersamasama debu menyebar ke mana-mana [9].

Pada sarana pembuangan air limbah (SPAL) ada sebagian responden yang membuang air limbahnya dialirkan langsung ke sungai dekat rumah tanpa dibuatkan saluran khusus. Hal ini dapat menjadi penyebab penularan penyakit sesuai teori dari Notoatmodjo [5], bahwa air buangan atau air limbah yang akan dibuang ke sungai atau ke laut dibuatkan saluran khusus karena akan digunakan kembali, oleh sebab itu 
air buangan ini harus dikelola secara baik agar tidak terjadinya penularan penyakit.

Lingkungan merupakan salah satu faktor yang menyebabkan terjadinya suatu penyakit. Lingkungan yang dimaksud dalam hal ini adalah lingkungan fisik berupa rumah. Rumah merupakan salah satu faktor yang tampak oleh mata dan dapat dilakukan penilaian tentang kesehatannya.

Lingkungan yang buruk tentu akan mengganggu keseimbangan di mana proses interaksi terjadinya suatu penyakit melibatkan dua faktor lain yaitu agent dan host. Proses itu berjalan dinamis dan jika salah satu terganggu maka akan mempengaruhi yang lainnya dan akan menyebabkan terjadinya penyakit pada host [10]. Kondisi lingkungan yang tidak sehat juga akan meningkatkan agent penyebab penyakit untuk berkembang biak dan akan memudahkan proses penularan penyakit yang dalam hal ini adalah infeksi saluran pernapasan akut (ISPA). Maka dapat disimpulkan bahawa kebersihan rumah merupakan salah satu faktor penyebab kejadian ISPA pada balita.

\section{E. KESIMPULAN}

1. Kebersihan rumah di Dusun Jabon Desa Sisik Wilayah kerja Puskesmas Bagu Kecamatan Pringgarata Kabupaten Lombok Tengah tahun 2018 termasuk dalam kategori bersih yaitu lima puluh enam persen dan kategori tidak bersih empat puluh empat persen

2. Kejadian Infeksi Saluran Pernafasan Akut (ISPA)pada Balita di Dusun Jabon Desa Sisik Wilayah kerja Puskesmas Bagu Kecamatan Pringgarata Kabupaten Lombok Tengah tahun 2018 adalah sebanyak dua belas orang yaitu tiga puluh tujuh koma lima persen yang terkena penyakit ISPA dan dua puluh orang yaitu enam puluh dua koma lima persen yang tidak ISPA.
3. Hasil Analisa Hubungan Kebersihan Rumah Terhadap Kejadian ISPA pada Balita di Dusun Jabon Desa Sisik Wilayah kerja Puskesmas Bagu Kecamatan Pringgarata Kabupaten Lombok Tengah tahun 2018 yaitu ada hubungan yang signifikan antara kebersihan rumah dengan kejadian ISPA pada balita (personchi-square $=0,002$ )

\section{F. Saran}

\section{Bagi Masyarakat}

Diharapkan bagi masyarakat umum khususnya keluarga yang mempunyai balita untuk memelihara kesehatan lingkungan khususnya kebersihan rumah agar terhindar dari resiko terjadinya berbagai penyakit infeksi khususnya penyakit ISPA pada balita.

\section{Bagi Pihak Puskesmas}

Diharapkan kepada pihak puskesmas agar terus melakukan dan meningkatkan penyuluhan dan sosialisasi kepada seluruh masyarakat baik secara individu maupun kelompok mengingat dengan penyuluhan maupun konseling dapat meningkatkan pengetahuan dan pemahaman masyarakat khususnya yang mempunyai balita, menyangkut pentingnya untuk menjaga kesehatan dan kebersihan lingkungan khususnya kebersihan rumah. Kepada peneliti diharapkan dapat lebih mengembangkan dan mencari faktor lain yang dapat mempengaruhi kejadian ISPA pada balita, serta meningkatkan kepekaan dan kepedulian sosial terkait masalah kesehatan masyarakat.

\section{Bagi Institusi Pendidikan}

Mengingat perkembangan ilmu keperawatan khususnya terkait dengan Kebersihan Rumah Terhadap Kejadian ISPA pada Balita dan hasil penelitian ini 
diharapkan dapat di pergunakan sebagai bahan pertimbangan dalam proses pembelajaran dan tindakan mencegah terjadinya ISPA pada balita.

\section{Bagi Peneliti Lain}

Diharapkn peneliti lain dapat mengembangkan penelitiannya dengan melakukan observasi langsung serta menambahkan faktor- faktor lain yang dapat mempengaruhi terjadinya ISPA pada balita.

\section{DAFTRA PUSTAKA}

[1] Litbangkes, (2013). Jurnal Kesehatan Rumah, Media Litbang Kesehatan Volume $X$ Nomor 2 tahun (2010).

[2] Notoadmodjo,S. Methodologi penelitian keperawatan. Jakarta: Rineka cipta.

[3] Norihwadziyah \& Keman, S. (2012). Hubungan Kesehatan Rumah dengan Kejadian ISPA pada Anak Balita, kota waringin timur, (2012).
[4] Riset Kesehatan Dasar (Riskesdas) (2013). Badan Penelitian dan Pengembangan Kesehatan Kementerian RI tahun 2013. http://kesga.kemkes.go.id/images/pedoman/ Data\%20Riskesdas\%202013.pdf

[5] Notoadmodjo,S (2013). Methodologi penelitian keperawatan. Jakarta: Rineka cipta.

[6] Misnadiarly. (2008). Penyakit Infeksi Saluran Napas Pneumoni pada Anak Orang Dewasa, Usia Lanjut. Edisi 1. Jakarta : Pustaka Obor Populer.

[7] Widiati, S. (2001). Planet Kita Kesehatan Kita : Laporan Komisi WHO Mengenai Kesehatan dan Lingkungan. Yogyakarta : Universitas Gajah Mada Press.

[8] Hadi., W. (2015). Hubungan Prilaku Hidup Bersih Dan Sehat (PHBS) Keluarga Dengan Kejadian Pneumonia Pada Balita, Pringgarata, 2015.

[9] Kasnodiharjo, Elsa. E. (2013). Deskripsi sanitasi lingkungan, perilaku ibu dan kesehatan anak.

[10] Mubarak, W, I \& Chayatin, N (2009). Ilmu Keperawatan Komunitas Pengantar dan Teori. Jakarta : Salemba Medika. 